\title{
Inheritance of Soluble Solids and Pyruvic Acid Content of Bulb Onions
}

\author{
Mau-Wei Lin ${ }^{1}$, James F. Watson ${ }^{2}$, and James R. Baggett ${ }^{3}$ \\ Department of Horticulture, Oregon State University, Agricultural and Life Sciences Building 4017, \\ Corvallis, OR 97331-7304
}

Additional index words. vegetable breeding, Allium cepa

\begin{abstract}
Analysis of parents and progeny generations of bulb onion (Allium cepa L.) crosses among parents with differing content of soluble solids (SS) and pyruvic acid (PA) showed that SS and PA are expressed and inherited in a quantitative manner. Distribution of SS and PA in both parents and progenies covered a range of values. Generation means, frequency distributions, deviation from midparent value, and estimates of gene effects all indicated that inheritance of SS and PA was additive, except for small deviations from the additive hypothesis in several individual backcrosses. Estimates of broad-sense heritability ranged from $48 \%$ to $53 \%$ for PA and $8 \%$ to $56 \%$ for SS. Phenotypic correlations between PA and SS estimated from the $\mathrm{F}_{2}$ generations of two crosses, were moderate and positive $(r=0.50$ and 0.42$)$.
\end{abstract}

Among cultivars of bulb onions, dry matter content, consisting mostly of fiber, starch, and sugars, is an important quality factor determining bulb uses. High dry matter onions are required for dehydration (Grieg and Marine, 1965; Owen, 1961) and have better storage quality (Foskett and Peterson, 1949). Dry matter content was shown by Platenius and Knott (1941) to reflect pungency level, which is a major factor affecting onion flavor. Schwimmer and Guadagni (1962) also found a medium correlation $(r=0.57)$ between total solids and pungency. Mild, lowpungency onions were more susceptible to storage rots such as neck rot (Owen et al., 1950). Jones and Bisson (1934) found that mild, high-moisture (low solids) onions had lower storage quality than pungent, low-moisture (high solids) onions.

Analysis of dry matter content in onions ordinarily requires oven-drying methods that are time consuming and destroy the bulbs. It has been determined (Mann and Hoyle, 1945; Foskett and Peterson, 1949) that refractive index [soluble solids (SS)] is highly correlated with percent dry matter and can be obtained without destruction of a bulb to be used for breeding.

Onion pungency is difficult to measure by taste test because of the accumulative effect of successive tasting (Platenius and Knott, 194 1) and can be more accurately determined by analysis of biochemical components or derivatives. It has been shown that the content of pyruvic acid (PA), which develops through enzymatic action within a few minutes after onion tissue is macerated, is highly related to degree of onion pungency (Bennet, 1945; Morgan, 1946; Schwimmer and Weston, 1961).

McCollum (1968) reported that the heritability of SS was high and that there was a negative genetic correlation between SS and bulb size. Warid (1952) also found high heritability (71\%) and concluded that four to ten gene pairs and partial dominance of low SS were involved in his cross, studied in the greenhouse. Owen (1961) postulated that cumulative gene action and a relatively small number of genes were involved in SS inheritance.

The inheritance of pungency was studied by Pal and Singh

Received for publication 23 Mar. 1994. Accepted for publication 25 July 1994. Oregon Agricultural Experiment Station technical paper no. 10,449.The cost of publishing this paper was defrayed in part by the payment of page charges. Under postal regulations, this paper therefore must be hereby marked advertisement solely to indicate this fact.

${ }^{1}$ Former graduate research assistan.Current address: Horticulture Department, National Ping-Tung Institute of Agriculture, Ping-Tung, Taiwan, R.O.C. 900. ${ }^{2}$ Courtesy assistant professor and plant breeder, Sunseeds Co., Brooks, OR 97305. ${ }^{3}$ Professor.
(1988) using parental and F, data from an eight parent diallel cross. They reported that PA was controlled by additive and dominant gene action, with additive gene action more important.

Because of the relationships between low pungency, low dry matter, poor storage quality, and susceptibility to neck rot, the development of mild onions with good keeping quality is a difficult challenge for breeders. The objective of the study reported here was to determine the inheritance of SS (as an indication of total dry matter) and PA content (as an indicator of pungency) and their correlation.

\section{Materials and Methods}

Inbred onion lines used as parents were W202, W407, and W420 from the Univ. of Wisconsin, B6693 from the U.S. Dept. of Agriculture, Pg-1 (Pg) from the Idaho Agricultural Experiment Station, and WSS D10-1 (D10) from Sunseeds Co. Four crosses were made between parents with higher SS and PA and parents lower in SS and PA. One additional cross (W420 × B6693) involved parents with similar SS. Inheritance of PA was studied only in two crosses $(\mathrm{W} 420 \times \mathrm{Pg}$ and $\mathrm{W} 420 \times \mathrm{B} 6693)$.

Seeds of the F, generation were obtained by hand emasculation and pollination. The parents were selfed by using flies as pollinators in small cages. To obtain $\mathrm{F}_{2}$ seed and make backcrosses, $\mathrm{F}_{1}$ and parent seeds were planted in the greenhouse in September 1986, vernalized in pots, and flowered in June and July 1987. Selfing of the $\mathrm{F}_{1}$ and parent plants was done on an individual plant basis using flies as pollinators. Additional $\mathrm{F}_{1}$ seeds and backcrosses were obtained by hand emasculation and pollination by hand or by flies. To avoid contamination, umbels of female plants were covered with paper bags before pollination.

To produce bulbs for SS and PA analysis, seeds of all generations were planted in the greenhouse on 19 Mar. Plants were grown in seedling trays for 6 weeks, then transplanted to the field in rows $0.5 \mathrm{~m}$ apart with $9 \mathrm{~cm}$ between plants, arranged in a randomized complete block with four replications. In each replication, the six generations of a single cross were randomized in one row. Cultural methods were typical of commercial mineral soil production of onions in western Oregon. Bulbs were dug 15 Sept., field cured for 3 weeks, cleaned, and stored at 5 to 10C. SS analyses were done in October to January. PA analyses were done in February to March.

Randle (1992) evaluated sampling procedures to estimate PA and SS in onion varieties and reported that sensitivity sufficient to detect a difference of $1 \% \mathrm{SS}$ and $1 \mu \mathrm{mol} \cdot \mathrm{g}^{-1}$ fresh weight PA was 
Table 1. Generation means of percent soluble solids of onion bulbs.

\begin{tabular}{|c|c|c|c|c|}
\hline \multirow[b]{2}{*}{ Cross } & \multirow[b]{2}{*}{ Generation $^{2}$} & \multirow[b]{2}{*}{ No. bulbs ${ }^{y}$} & \multicolumn{2}{|c|}{ Soluble solids $(\%)$} \\
\hline & & & Mean & SD \\
\hline \multirow[t]{7}{*}{$\overline{\mathrm{W} 420 \times \mathrm{Pg}}$} & $\mathrm{P}_{1}$ & 64 & 11.8 & 0.8 \\
\hline & $\mathrm{P}_{2}$ & 54 & 7.2 & 0.7 \\
\hline & $F_{1}$ & 49 & 10.1 & 0.9 \\
\hline & $\mathrm{F}_{2}$ & 98 & 9.5 & 1.2 \\
\hline & $\mathrm{BC}_{1}$ & 64 & 12.0 & 0.7 \\
\hline & $\mathrm{BC}_{2}$ & 45 & 8.6 & 1.1 \\
\hline & $\mathrm{LSD}_{0.05}$ & & 0.7 & \\
\hline \multirow[t]{7}{*}{ W420 x D 10} & $\mathrm{P}_{1}$ & 64 & 12.1 & 0.8 \\
\hline & $\mathrm{P}_{2}$ & 64 & 9.1 & 1.4 \\
\hline & $\mathrm{F}_{1}$ & 12 & 10.6 & 0.7 \\
\hline & $\mathrm{F}_{2}$ & 95 & 10.7 & 1.2 \\
\hline & $\mathrm{BC}_{1}$ & 64 & 11.1 & 1.1 \\
\hline & $\mathrm{BC}_{2}$ & 55 & 10.3 & 1.2 \\
\hline & $\mathrm{LSD}_{0.05}$ & & 0.7 & \\
\hline \multirow[t]{7}{*}{$\mathrm{W} 202 \times \mathrm{D} 10$} & $\mathrm{P}_{1}$ & 64 & 10.1 & 0.7 \\
\hline & $\mathrm{P}_{2}$ & 63 & 7.5 & 0.8 \\
\hline & $F_{1}$ & 52 & 9.4 & 1.0 \\
\hline & $\mathrm{F}_{2}$ & 95 & 9.6 & 1.1 \\
\hline & $\mathrm{BC}_{1}$ & 59 & 9.5 & 0.9 \\
\hline & $\mathrm{BC}_{2}$ & 29 & 7.1 & 0.7 \\
\hline & $\mathrm{LSD}_{0.05}$ & & 0.4 & \\
\hline \multirow[t]{7}{*}{$\mathrm{B} 6693 \times \mathrm{Pg}$} & $\mathrm{P}_{1}$ & 63 & 10.3 & 0.9 \\
\hline & $\mathrm{P}_{2}$ & 64 & 7.5 & 0.8 \\
\hline & $\mathrm{F}_{1}$ & 25 & 9.0 & 1.1 \\
\hline & $\mathrm{F}_{2}$ & 116 & 9.3 & 1.1 \\
\hline & $\mathrm{BC}_{1}$ & 64 & 10.0 & 1.0 \\
\hline & $\mathrm{BC}_{2}$ & 64 & 8.6 & 1.1 \\
\hline & $\mathrm{LSD}_{0.05}$ & & 0.9 & \\
\hline \multirow[t]{7}{*}{ W420 x B6693 } & $\mathrm{P}_{1}$ & 60 & 9.3 & 0.9 \\
\hline & $\mathrm{P}_{2}$ & 46 & 9.5 & 1.0 \\
\hline & $\mathrm{F}_{1}$ & 62 & 10.3 & 0.6 \\
\hline & $\mathrm{F}_{2}$ & 107 & 10.1 & 0.8 \\
\hline & $\mathrm{BC}_{1}$ & 62 & 10.4 & 0.6 \\
\hline & $\mathrm{BC}_{2}$ & 62 & 10.2 & 0.9 \\
\hline & $\mathrm{LSD}_{0.05}$ & & 0.4 & \\
\hline
\end{tabular}

$\overline{{ }^{2} C_{1}}=\overline{F_{1}} \times \overline{P_{1}} ; \mathrm{BC}_{2}=\overline{F_{1}} \times \overline{\mathrm{P}_{2}}$.

yTotal number of bulbs in four replications analyzed for soluble solids.

achieved by analysis of 20 bulbs per variety. The number of bulbs analyzed for each generation in the present study is shown for SS in Table 1 and for PA in Table 4.

SS measurement. Two rectangular scale pieces were cut from the second and third layer (counting from the outer scale) of each bulb. Juice was squeezed from the scale pieces directly onto a hand refractometer with a hand garlic press. After the SS values were read, the refractometer and garlic press were washed with distilled water in preparation for the next sample (Mann and Hoyle, 1945).
$P A$ determination. The content of PA released after blending scale flesh with water was used as a measure of pungency (Schwimmer and Weston, 1961). After removal of the true stem and the dry outer scales, one-half to one-third of the bulb was weighed and placed in a mason jar with an equal weight of distilled water and blended $40 \mathrm{sec}$. After 12 jars had been blended, samples were let stand $10 \mathrm{~min}$ to allow the formation of PA. The onion juice was then filtered into a test tube through \#4 filter paper.

Using an automatic pipette, $2 \mathrm{ml}$ of filtrate was transferred into a volumetric flask, diluted to $100 \mathrm{ml}$ with distilled water, and then shaken. Two $\mathrm{ml}$ of the dilute solution was then placed in a test tube to which had been added $1 \mathrm{ml}$ of DNPH $(0.0125 \%$ 2,4-dinitrophenyl hydrazine in $2 \mathrm{~N} \mathrm{HCI}$ ). A rack of 12 tubes was placed into a 37C water bath. After exactly 10 rein, the reaction was stopped by adding $5 \mathrm{ml}$ of $0.6 \mathrm{~N} \mathrm{NaOH}$ to each tube. The samples were then allowed to stand for $5 \mathrm{~min}$ for color development.

Absorbance of each sample was measured with a spectrophotometer set at $420 \mathrm{~nm}$, using a reagent blank set at 0 absorbance (2 $\mathrm{ml}$ water $+1 \mathrm{ml} \mathrm{DNPH}+5 \mathrm{ml} \mathrm{NaOH})$. A standard curve for calibration was obtained by using sodium pyruvate as a reagent with gradient concentrations of PA. Absorbance was read to get a standard curve of PA for transforming the spectrophotometer reading into PA concentration.

\section{Results and Discussion}

The data obtained from parents and progenies of the six crosses for SS and the two crosses for PA showed that both characteristics are highly quantitative in their expression. In each case, the parents and $F_{1}$ as well as the segregation generations produced a range of values, and generations tended to overlap. While some of the variation in parents and $F_{1}$ could result from a degree of heterozy gosity in the parents, it is considered to be mostly due to the effects of environment and the nature of the expression of these characters.

SS. The generation means for SS strongly indicated additive inheritance (Table 1). The $\mathrm{F}_{1}$ and $\mathrm{F}_{2}$ means were usually intermediate between parents. In W420 × B6693, the cross between two high SS parents, there was a suggestion of heterosis for SS, and the $\mathrm{F}$, was significantly different than the midparent at 0.05 probability. Two backcrosses among the six crosses were also significantly different than their midparent values (Table 2), but these did not fit a pattern.

Frequency distributions (Fig. 1) indicated additive inheritance with little skewing of generations that would suggest dominance. Backcrosses approached their respective parents and usually were more broadly distributed. In $\mathrm{W} 420 \times \mathrm{Pg}, \mathrm{BC}_{1}$ (Fig. 1A) tended to be slightly higher in SS than PI, as also shown by generation means. In $420 \times \mathrm{D} 10$ (not shown), $\mathrm{P}_{2}$ covered a very wide range, the $\mathrm{F}_{1}$ and parental peaks were well separated, and the $F_{1}, F_{2}$, and backcrosses fit the expected pattern for additive inheritance. W202 $\times$ D10 (Fig.

Table 2. Deviation from mid-parent values of mean soluble solids and pyruvic acid content of $F_{1}$ generations and backcrosses. ${ }^{2}$

\begin{tabular}{|c|c|c|c|c|c|c|}
\hline \multirow[b]{2}{*}{ Cross } & \multicolumn{3}{|c|}{ Soluble solids $(\%)$} & \multicolumn{3}{|c|}{ Pyruvic acid $\left(\mu \mathrm{mol} \cdot \mathrm{g}^{-1}\right)$} \\
\hline & $\mathrm{F}_{1}-\mathrm{MP}$ & $\mathrm{BC}_{1}-\mathrm{MP}$ & $\mathrm{BC}_{2}-\mathrm{MP}$ & $\mathrm{F}_{1}-\mathrm{MP}$ & $\mathrm{BC}_{1}-\mathrm{MP}$ & $\mathrm{BC}_{2}-\mathrm{MP}$ \\
\hline$\overline{\mathrm{W} 420 \times \mathrm{Pg}}$ & $0.60^{\mathrm{NS}}$ & $1.01^{*}$ & $-0.08^{\mathrm{NS}}$ & $-0.04^{\mathrm{NS}}$ & $2.03^{* *}$ & $-0.28^{\mathrm{NS}}$ \\
\hline W202 $\times$ D 10 & $0.61^{\mathrm{NS}}$ & $-0.26^{\mathrm{NS}}$ & $-1.36^{* *}$ & & & \\
\hline $\mathrm{W} 420 \times \mathrm{D} 10$ & $-0.04^{\mathrm{NS}}$ & $-0.22^{\mathrm{NS}}$ & $0.50^{\mathrm{NS}}$ & & & \\
\hline $\mathrm{B} 6693 \times \mathrm{Pg}$ & $0.09^{\mathrm{Ns}}$ & $0.38^{\mathrm{NS}}$ & $0.35^{\text {NS }}$ & & & \\
\hline $\mathrm{W} 420 \times \mathrm{B} 6693$ & $0.89^{*}$ & $0.62^{\mathrm{NS}}$ & $0.29^{\mathrm{NS}}$ & $0.48^{\mathrm{NS}}$ & $0.14^{\text {NS }}$ & $-0.19^{\mathrm{NS}}$ \\
\hline
\end{tabular}

$\overline{\mathrm{BC}_{1}}=$ backcross $\overline{\mathrm{F}_{1}} \times \mathrm{P}_{1} ; \overline{\mathrm{BC}}_{2}=$ backcross $\mathrm{F}_{1} \times \mathrm{P}_{2}$.

Ns,*, ${ }^{* *}$ Nonsignificant or significant at $P=0.05$ or 0.01 , respectively. 

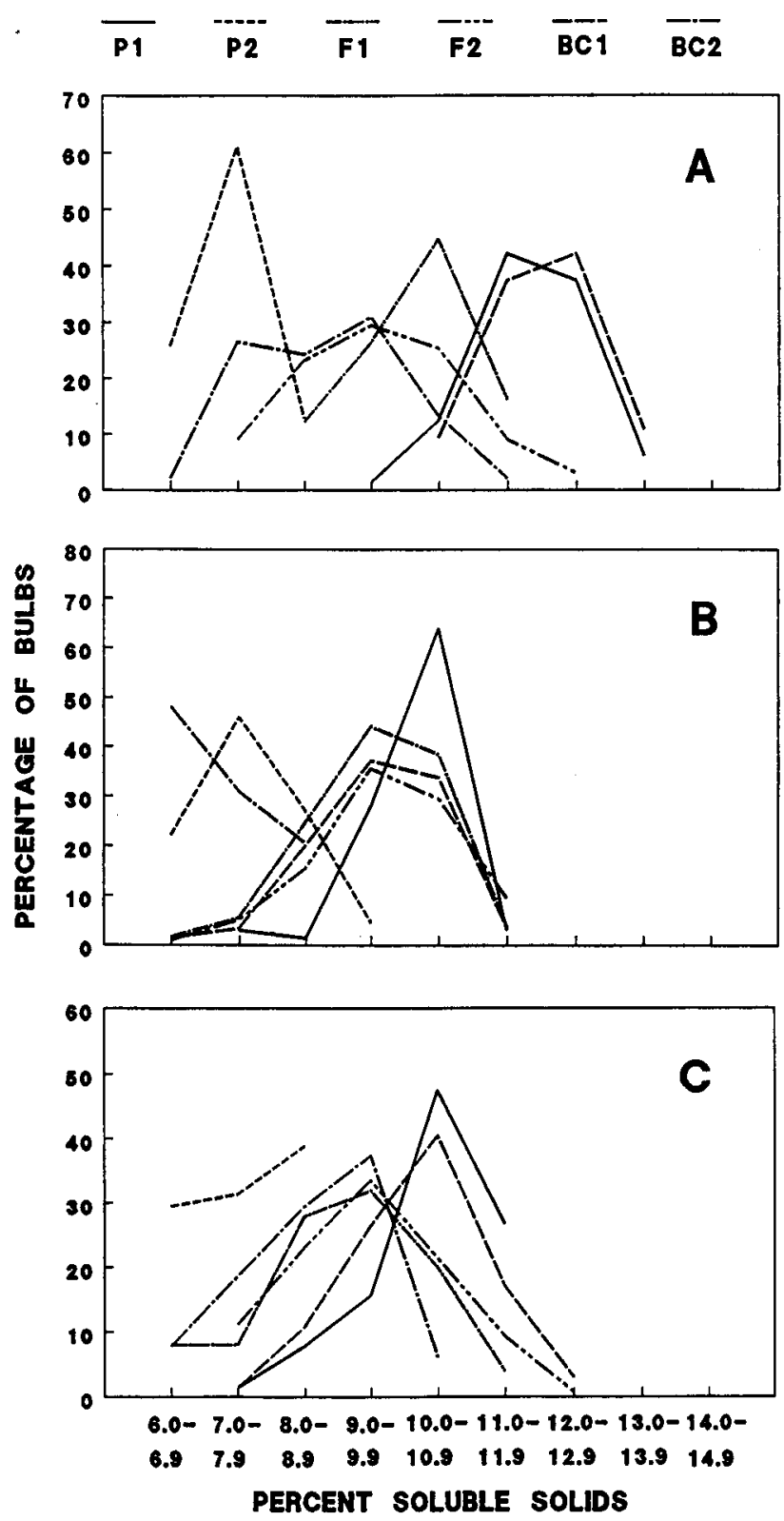

Fig. 1. Frequency distributions for percent soluble solids (SS) in generations of onion crosses (A) W420 x Pg, (B) W202 x D10, and (C) B6693 X Pg.

1B) showed a smaller spread between parents, but clear separation, and some indication of skewing of the $F_{1}$ and $F_{2}$ toward PI, which was also apparent in generation means. In B6693 × P6 (Fig. 1 C), $\mathrm{B}_{1}$ and the $\mathrm{F}_{2}$ were somewhat transgressive to $\mathrm{P}_{1}$, but otherwise this cross fit an additive pattern.

The estimates of gene effects for SS are presented in Table 3. The Chi-square tests for deviations from the three-parameter model (Hayman, 1958) were nonsignificant for all crosses except W202 $\times$ D10. The deviations from additivity for SS in this cross are due to the low SS level in the $\mathrm{BC}_{2}$ generation. This can be seen in the population means (Table 1) and in the significant deviation of $\mathrm{B} \mathrm{C}_{2}$ from its midparent value (Table 2). Hayman (1958) showed that the best approximations of additive and dominance effects are provided by estimates from the three-parameter model even when a significant chi-square for deviations from the model is obtained. Thus, no application of the six-parameter model was made. In each of the four crosses where parents differed significantly in SS content $(\mathrm{W} 420 \times \mathrm{Pg}, \mathrm{W} 202 \times \mathrm{D} 10, \mathrm{~W} 420 \times \mathrm{D} 10$, and B6693 $\times \mathrm{Pg}$ ),
Table 3. Estimates of gene effects for soluble solids content from generation means using a three-parameter model.'

\begin{tabular}{|c|c|c|c|c|}
\hline \multirow[b]{3}{*}{ Cross } & \multicolumn{3}{|c|}{ Gene effect } & \multirow[b]{3}{*}{$x^{2}$} \\
\hline & \multicolumn{3}{|c|}{ Three-parameter model } & \\
\hline & Mean & Additive & Dominance & \\
\hline$\overline{\mathrm{W} 420 \times \mathrm{Pg}}$ & $9.9 * *$ & $2.4 * *$ & 0.7 & $3.30^{\mathrm{NS}}$ \\
\hline $\mathrm{W} 202 \times \mathrm{D} 10$ & $8.7 * *$ & $1.5^{* *}$ & 0.3 & $7.80 *$ \\
\hline $\mathrm{W} 420 \times \mathrm{D} 10$ & $10.6^{* *}$ & $1.6^{*}$ & -0.1 & $0.30^{\mathrm{NS}}$ \\
\hline $\mathrm{B} 6693 \times \mathrm{Pg}$ & $9.1 * *$ & $1.5^{* *}$ & 0.3 & $1.95^{\mathrm{NS}}$ \\
\hline $\mathrm{W} 420 \times \mathrm{B} 6693$ & $10.0^{*}$ & 0.5 & $4.4^{* *}$ & $2.50^{\mathrm{NS}}$ \\
\hline
\end{tabular}

${ }^{2}$ Hayman (1958).

${ }^{\mathrm{Ns}, * * *}$ Nonsignificant or significant at $P=0.05$ or 0.01 , respectively.

Table 4. Generation means of pyruvic acid content of onion bulbs.

\begin{tabular}{|c|c|c|c|c|}
\hline \multirow[b]{2}{*}{ Cross } & \multirow[b]{2}{*}{ Generation $^{2}$} & \multirow[b]{2}{*}{ No. bulbs } & \multicolumn{2}{|c|}{ Pyruvic acid $\left(\mu \mathrm{mol} \cdot \mathrm{g}^{-1}\right)$} \\
\hline & & & Mean & $\mathrm{SD}$ \\
\hline \multirow[t]{7}{*}{$\mathrm{W} 420 \times \mathrm{Pg}$} & $\mathrm{P}_{1}$ & 64 & 13.2 & 1.6 \\
\hline & $\mathrm{P}_{2}$ & 54 & 8.7 & 1.1 \\
\hline & $\mathrm{F}_{1}$ & 49 & 10.9 & 1.2 \\
\hline & $\mathrm{F}$ & 98 & 11.4 & 1.9 \\
\hline & $\mathrm{B} \mathrm{C}_{1}$ & 64 & 14.1 & 1.5 \\
\hline & $\mathrm{B} \mathrm{C}_{2}$ & 45 & 9.5 & 1.5 \\
\hline & $\mathrm{LSD}_{\mathrm{0} .05}$ & & 0.8 & \\
\hline \multirow[t]{7}{*}{$\mathrm{W} 420 \times \mathrm{B} 6693$} & $\mathrm{P}_{1}$ & 60 & 14.2 & 1.9 \\
\hline & $\mathrm{P}_{2}$ & 46 & 10.9 & 0.7 \\
\hline & $\mathrm{F}_{1}$ & 62 & 13.0 & 1.2 \\
\hline & $\mathrm{F}_{2}$ & 107 & 12.2 & 1.6 \\
\hline & $\mathrm{BC}_{1}$ & 62 & 13.8 & 1.7 \\
\hline & $\mathrm{B} \mathrm{C}_{2}$ & 62 & 11.8 & 1.4 \\
\hline & $\mathrm{LSD}_{0.05}$ & & 1.3 & \\
\hline
\end{tabular}

${ }^{2} \mathrm{BC}_{1}=\mathrm{F}, \times \mathrm{P} ; \mathrm{BC}_{2}=\mathrm{F}_{1} \times \mathrm{P}_{2}$. Reciprocal backcrosses combined.

'Total number of bulbs in four replications tested for pyruvic acid content.

the three-parameter model estimates of additive gene effects were significant and larger than the dominance effects, which were in no case significant. The additive effects for SS in all crosses were relatively small compared to mean effects, indicating that increasing and decreasing alleles for SS are not highly associated in these parents; that is, some increasing alleles may be present in the low SS parents.

The estimate of gene effects for SS in the cross W420 × B6693 (Table 3) is the only instance in these data where the dominance effect was highly significant while the additive effect was not significantly different than zero. This heterotic response has previously been noted as evident in generation means (Table 1) and is also reflected by the significant deviation of the $F_{1}$ from the midparent (Table 2).

$P A$ content. The principal deviation from an additive inheritance pattern was shown by the generation means of $\mathrm{W} 420 \times \mathrm{Pg}$, where $\mathrm{BC}_{1}$ exceeded $\mathrm{P}_{1}$ significantly (Table 4). This behavior of $\mathrm{BC}_{1}$ was also expressed in the frequency distribution for $\mathrm{W} 420 \times$ $\mathrm{Pg}$ (Fig. 2A). Otherwise, the generation means and frequency distributions of this cross suggested that PA was inherited in an additive manner. While the $\mathrm{F}_{2}$ did not cover the entire range of the parents, its pattern (Fig. 2A) was symmetrical and showed no evidence of dominance.

Generation PA means for W420 × B6693 showed a clearly additive pattern. In the frequency distributions (Fig. 2B), the $\mathrm{F}_{2}$ covered the entire PA range but was slightly skewed toward the low PA parent $\left(\mathrm{P}_{2}\right)$, while the backcrosses and $\mathrm{F}_{1}$ were about as 

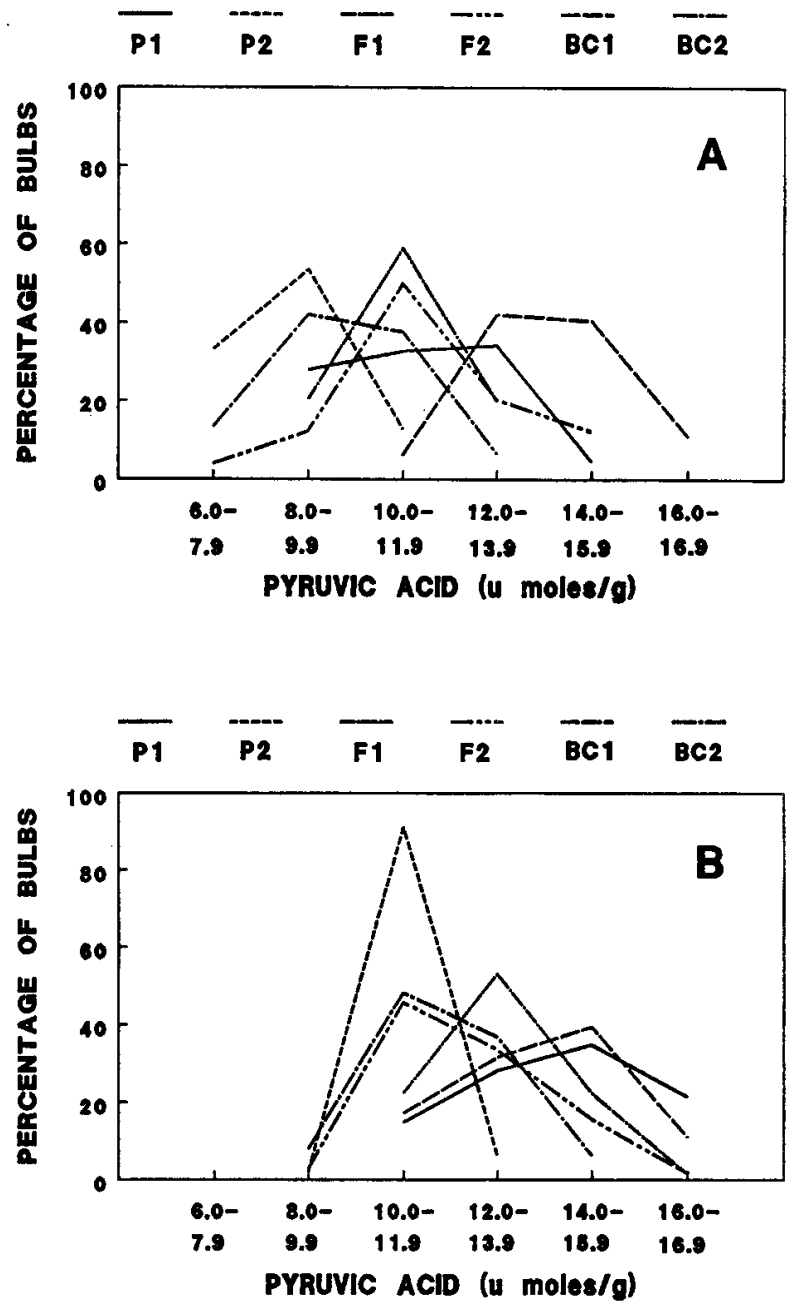

Fig. 2. Frequency distributions for pyruvic acid content (PA) in generations of onion crosses (A) W420 $\times$ Pg and (B) W420 × B6693.

expected for additive inheritance. In this cross, $\mathrm{P}_{2}$ was unusually concentrated with a strong peak over about $10 \mu \mathrm{mol} \cdot \mathrm{g}^{-1}$, while the other populations showed the usual spread.

When gene effects were calculated, the chi-square value resulting from deviations from the three-parameter model for PA was highly significant in the cross $\mathrm{W} 420 \times \mathrm{Pg}$ (Table 5), indicating that the additive-dominance model does not adequately describe these data. This deviation from additivity in $\mathrm{W} 420 \times \mathrm{Pg}$ was due to the high PA level of the $\mathrm{BC}_{1}$ generation, which was also reflected in the significant deviation of the $\mathrm{BC}_{1}$ generation from its midparent value (Table 2). The variation for PA in the cross $\mathrm{W} 420 \times \mathrm{B} 6693$, in contrast, was adequately described by the additive-dominance model; and the dominance effect was not significant while the additive effect was significant at 0.05 probability.

Heritability of SS and PA. Estimates of broad-sense heritability ranged from $48 \%$ to $53 \%$ for PA, and $8 \%$ to $56 \%$ for SS (Table 6). The heritability value for SS in individual crosses was related to the degree of difference in the traits between parents. Higher heritability was found in the crosses which had large parental difference in SS, but values were low in W420 × B6693 and W407 $\times$ D 10 .

Correlation among traits. Phenotypic correlations between PA and SS were estimated using the $\mathrm{F}_{2}$ generations of the crosses $\mathrm{W} 420 \times \mathrm{Pg}$ and W420 $\times 6693$. Phenotypic correlations between PA and SS were positive, moderate, and significant in both crosses $(r$ $=0.50$ and 0.42 , respectively). This agrees with the earlier reports
Table 5. Estimates of gene effects for pyruvic acid content from generation means using a three-parameter model. ${ }^{\mathrm{z}}$

\begin{tabular}{|c|c|c|c|c|}
\hline \multirow[b]{2}{*}{ Cross } & \multicolumn{3}{|c|}{ Gene effect } & \multirow[b]{2}{*}{$x^{2}$} \\
\hline & Mean & Additive & Dominance & \\
\hline $\mathrm{W} 420 \times \mathrm{Pg}$ & $9.2^{* *}$ & $2.7^{* *}$ & 0.2 & $29.9^{* *}$ \\
\hline $\mathrm{W} 420 \times \mathrm{B} 6693$ & $11.8^{* *}$ & $1.7^{*}$ & 0.5 & $3.16^{\mathrm{NS}}$ \\
\hline \multicolumn{5}{|c|}{$\begin{array}{l}\text { "zHayman (1958). } \\
\text { Ns,*,** Nonsignificant or significant at } P=0.05 \text { or } 0.01 \text {, respectively. }\end{array}$} \\
\hline \multicolumn{5}{|c|}{$\begin{array}{l}\text { Table 6. Estimates of broad-sense heritability of pyruvic acid and soluble } \\
\text { solids content of bulb onions. }\end{array}$} \\
\hline & & \multicolumn{3}{|c|}{ Broad-sense heritability (\%) } \\
\hline Cross & & Soluble solids & & Pyruvic acid \\
\hline $\mathrm{W} 420 \times \mathrm{Pg}$ & & 56 & & 53 \\
\hline W202 x D10 & & 49 & & --- \\
\hline $\mathrm{W} 420 \times \mathrm{D} 10$ & & 41 & & --- \\
\hline B6693 x Pg & & 34 & & --- \\
\hline $\mathrm{W} 420 \times \mathrm{B} 6693$ & & 13 & & 48 \\
\hline
\end{tabular}

of Platenius and Knott (1941) and Schwimmer and Guadagni (1962). Because the compounds responsible for onion pungency also contribute to total dissolved solids, at least part of this positive correlation is due to the partial identity of the two traits.

\section{Literature Cited}

Bennet, E. 1945. A note on the presence of pyruvic acid in Ebenezer onions. Plant Physiol. 20:461-463.

Foskett, R.L. and C.E. Peterson. 1949. Relation of dry matter content to storage quality in some onion varieties and hybrids. Proc. Amer. Soc. Hort. Sci. 55:314-318.

Grieg, W.S. and C.L. Marine. 1965. Onions and their processing potentials. Michigan Agr. Expt. Sta. Res. Rpt. 14.

Hayman, B.I. 1958. The separation of epistatic from additive and dominance variation in generation means. Heredity 12:371-390.

Jones, H.A. and C.S. Bisson. 1934. Moisture content of different varieties of onions. Proc. Amer. Soc. Hort. Sci. 31:165-168.

Mann, L.K. and B.J. Hoyle. 1945. Use of the refractometer for selection of onion bulbs high in dry matter for breeding. Proc. Amer. Soc. Hort. Sci. 46:285-292.

McCollum, G.D. 1968. Heritability and genetic correlation of soluble solids, bulb size and shape in white Sweet Spanish onion. Can. J. Genet. Cytol. 10:508-514.

Morgan, E.J. 1946. Pyruvic acid in the juice of onion (Allium cepa). Nature 157:512.

Owen, E.W. 1961. The inheritance of dry matter in onion bulbs. MS thesis. Univ. Idaho, Moscow.

Owen, J. H., J.C. Walker, and M.A. Stahmann. 1950. Pungency, color and moisture supply in relation to disease resistance in the onion. Phytopathology 40:292-297.

Pal, N. and N. Singh. 1988. Analysis of genetic architecture of pungency (pyruvic acid) in onion. plant Breeding Abstr. 1988:379.

Platenius, H. and J.E. Knott. 1941. Factors affecting onion pungency. J. Agr. Res. 62:371-380.

Randle, W.M. 1992. Sampling procedures to estimate flavor potential in onion. HortScience 27:1116-1117.

Schwimmer, S. and D.G. Guadagni. 1962. Relation between olfactory threshold concentration and pyruvic acid content of onion juice. J. Food Sci. 27:94-97.

Schwimmer, S. and W.J. Weston. 1961. Enzymatic development of pyruvic acid in onion as a measure of pungency. J. Agr. Food Chem. 9:301-304.

Warid, W.A. 1952. Inheritance studies in the onion. PhD diss. Louisiana State Univ. 